\title{
Sistem Monitoring Alat Pendeteksi Asap Rokok Pada Ruangan Berbasis Mikrokontroler Menggunakan Mq-135 Dan Telegram
}

\author{
Egi Badar Sambani ${ }^{1}$, Dani Rohpandi ${ }^{2}$, Fahmi Akbar Fauzi ${ }^{3}$ \\ STMIK Tasikmalaya, Jl. RE Martadinata No 272 A, 0265-310830 \\ Jurusan Teknik Informatika, STMIK Tasikmalaya \\ E-mail : ${ }^{1}$ egibadar@gmail.com ${ }^{2}$ danirtms@gmail.com, ${ }^{3}$ akbarfauzif@gmail.com
}

\begin{abstract}
Abstrak
Asap rokok menjadi permasalahan yang sering muncul karena asap rokok selain berdampak pada kesehatan, asap rokok juga mencemari kualitas udara. Para perokok masih banyak yang melakukan pelanggaran yaitu merokok di area yang terdapat tanda dilarang merokok. Oleh karena itu, Peneliti membuat sebuah sistem monitoring alat pendeteksi asap rokok yang telah dikembangkan dari penelitian sebelumnya untuk mengontrol pelanggaran tersebut. Sistem monitoring asap rokok ini menghubungkan microcontroller dengan telegram yang ada pada smartphone, laptop dan komputer sehingga jangkauan monitoring menjadi lebih luas. Alat ini akan secara otomatis hidup ketika asap rokok terdeteksi. Didalam perangkat alat pendeteksi asap rokok terdapat mikrokontroler Wemos D1 ESP8266. Sedangkan sensor asap rokok menggunakan MQ-135.
\end{abstract}

Kata Kunci: Sensor MQ-135, Sistem Monitoring Asap Rokok, , Wemos Arduino, Telegram

\section{Abstract}

Cigerette smoke is a problem that often arises due to cigarette smoke in addition to impact on health, cigarette smoke also pollutes air quality. Many smokers who commit violations, namely smoking in areas where there are signs of no smoking. Therefore, the authors make a monitoring system for detecting cigarette smoke that has been developed from previous studies to control these violations. This cigarette smoke monitoring system connects the microcontroller with the telegram on smartphones, laptops and computers so that the monitoring range becomes wider. This tool will automatically turn on when cigerette smoke is detected. Inside the device for detecting cigarette smoke there is a microcontroller Wemos D1 ESP8266. While the cigarette smoke sensor uses MQ-135.

Keywords: MQ-135, Cigarette Smoke Monitoring System, Wemos Arduino, Telegram.

\section{PENDAHULUAN}

Seiring banyaknya perokok yang merokok di tempat umum, pemerintah menetapkan larangan untuk merokok ditempat umum sesuai yang diatur dalam Pasal 41 ayat (2) jo Pasal 13 ayat (1) Peraturan Daerah Nomor 2 Tahun 2005 yakni, setiap orang yang merokok dikawasan dilarang merokok diancam dengan pidana kurungan paling lama 6 (enam) bulan atau denda sebanyak-banyaknya Rp. 50 juta. Karena selain dapat mengganggu kesehatan, asap rokok juga mencemari kualitas udara. Apalagi umumnya orang-orang lebih banyak melakukan kegiatan di dalam ruangan, sehingga kualitas udara di dalam ruangan sangat penting. Untuk itu kebijakan tentang kawasan bebas rokok perlu dibuat untuk menjaga kesehatan dan kualitas udara dengan cara memberi peringatan tertulis tentang larangan merokok yang ditempel di tempat-tempat umum yang mudah terlihat. Kebijakan ini sudah diterapkan di sekolah-sekolah, rumah sakit, perkantoran dan beberapa tempat umum lainnya. Tetapi peringatan tertulis tentang larangan merokok ditempat umum ini masih sering diabaikan karena kurangnya kesadaran dari para perokok. Masih banyak perokok yang merokok di tempat-tempat umum yang terdapat peringatan larangan merokok.

Di negara berkembang, menurut survei demografi dan kesehatan yang berlangsung di 30 negara berkembang, $40 \%$ perempuan hamil terpapar asap rokok hampir setiap hari, $7 \%$ bayi lahir mati karena ibunya perokok pasif dan asap rokok menjadi sumber utama polusi udara dalam ruangan karena orang yang merokok di tempat umum masih banyak ditemui (Kamran, 
2018). Dan di negara berkembang, kesadaran akan bahaya terpapar asap rokok masih rendah. Budaya patriarki juga membuat perempuan menjadi kesulitan untuk menegur orang yang merokok di dekatnya.

Untuk itu, selain peringatan tertulis perlu juga dibuatkannya suatu sistem yang baik dan cepat serta dapat memonitoring juga memberikan peringatan kepada para pelanggar yang sering merokok ditempat umum yang terdapat larangan untuk merokok.Sistem ini akan lebih efisien daripada peringatan tertulis yang ditempel ditembok. Dengan adanya sistem ini juga akan lebih mempermudah pekerjaan manusia, karena sistem ini terhubung dengan telegram yang ada di smartphone, laptop, ataupun komputer, sehingga apabila sensor mendeteksi adanya asap rokok, maka akan muncul bunyi peringatan dan sistem ini juga akan memberikan notifikasi bahwa ada asap rokok yang terdeteksi ke telegram. Untuk melakukan penelitian ini, Peneliti mengambil 5 referensi jurnal yaitu :

"Rancang Bangun Alat Pendeteksi Asap Rokok Dan Nyala Api Untuk Penanggulangan Kesehatan Dan Kebakaran Berbasis Arduino Uno Dan GSM SIM900A" telah dibuat alat pendeteksi asap rokok dan nyala api dengan menggunakan sensor MQ-2 dan DFR0076 berbasis Arduino Uno dan GSM SIM900A. Alat ini diujicobakan pada ruangan/kotak yang berdimensi panjang $40 \mathrm{~cm}$, lebar $30 \mathrm{~cm}$, dan tinggi $30 \mathrm{~cm}$. Alat pendeteksi ini berfungsi sebagaimana mestinya sesuai dengan rancangan yang telah direncanakan dan sesuai harapan. Sensor MQ-2 dapat mendeteksi kadar asap rokok hingga jarak $25 \mathrm{~cm}$ dari sumber asap rokok. Semakin dekat sumber asap rokok maka nilai kadar asap rokok yang terdeteksi juga semakin besar yang berarti ruangan tidak sehat. Sensor DFR0076 juga dapat mendeteksi nyala api hingga jarak 25 $\mathrm{cm}$ dari sumber nyala api. Semakin dekat sumber nyala api maka nilai kadar nyala api terdeteksi juga semakin kecil yang berarti potensi kebakaran semakin besar. Alat kemudian akan mengirimkan informasi kepada pengguna.[1]

"Sistem Monitoring Realtime Gas Co Pada Asap Rokok Berbasis Mikrokontroler" Peraturan pemerintah No 32 tahun 2010 tentang larangan merokok di tempat-tempat umum, menyebabkan beragam macam bahaya asap rokok terhadap kesehatan. Zat berbahaya tersebut anatara lain karbonmonoksida (CO), dan nikotin. yang dapat menyebabkan penyakit seperti kangker, paru-paru, dan jantung. Dari hasil uji simulasi dan pembahasan tentang monitoring asap rokok dalam suatu ruangan secara realtime menggunakan Labview dapat disimpulkan bahwa rangkaian simulasi monitoring kadar gas $\mathrm{CO}$ pada asap rokok ini dengan menggunakan Mikrokontroler arduino uno dapat bekerja dengan baik sesuai karaktristik sensor MQ-2 yang digunakan dan kadar asap rokok yang terdapat di dalam ruangan telah berhasil ditampilkan di monitoring mengunakan sofware Labview.[2]

"Sistem Penyegaran Ruangan Dari Asap Rokok Dan Gas Lpg Berbasis Mikrokontroler ATMEGA8535" Asap rokok merupakan bahan penyebab terbanyak pencemaran udara terutama didalam ruangan yang sangat mengganggu dan berdampak pada kesehatan. Menurut DEPKES RI orang yang menghirup asap rokok akan menyebabkan kerusakan paru-paru, penyakit jantung, dan pada anak-anak akan mengalami batuk, pilek, dan radang tenggorokan serta penyakit paru-paru lebih tinggi. Asap rokok memiliki kandungan bahan kimia yang lebih dari empat ribu bahan kimia. Unsur yang terkandung tersebut bisa menyebabkan kerusakan pada sel DNA. Hal lain yang tidak kalah membahayakan yaitu gas LPG yang bagi sebagian orang merupakan energi alternatif yang digunakan untuk berbagai keperluan, karena harga yang murah dan penggunaan yang mudah serta efisien. Namun ada dampak negatif ketika menggunakan gas LPG di dalam rumah. Kebocoran tabung gas adalah masalah yang sering ditemukan karena akan menimbulkan kebakaran apabila tidak langsung ditangani. Perlu dirancang alat pengaman dari paparan asap rokok dan kebocoran gas LPG. rancangan alat penyegaran udara dari asap rokok dan gas LPG berbasis mikrokontroler ATMega 8535 dengan sensor MQ-9 ini melalui tahap pembuatan perangkap keras (hardware) dan perangkat lunak (software). Perangkat keras terdiri dari kotak yang merupakan prototype ruangan dan terdapat sensor MQ-9 untuk mendeteksi asap rokok dan gas LPG, mikrokontroler ATMega8535 sebagai pengendali, buzzer sebagai peringatan dini bahwa ada terdeteksi asap rokok dan gas LPG serta kipas yang akan aktif guna membuang asap rokok dan gas LPG dari dalam ruangan ke luar. Hasil akhir dari penelitian ini

menunjukkan bahwa telah berhasil dibuat prototype alat penyegaran udara dari asap rokok dan gas LPG menggunakan sensor MQ-9 yang akan mendeteksi kadar udara dalam ruangan, 100 sampai 1000 untuk asap rokok dan 100 sampai 10000 untuk gas LPG, dan akan ditampilkan pada LCD dalam satuan ppm. Ketika kadar udara dalam ruangan mencapai 300 ppm maka buzzer akan aktif dan kipas DC akan membuang udara dalam ruangan ke luar, sampai kadar dalam ruangan menjadi normal kembali.[3] 
Pada penelitian ini berjudul "Alat Pendeteksi Asap Rokok pada Ruangan Menggunakan Sensor MQ-2 dan Microkontroller Arduino Uno" Alat ini adalah sebuah

alat yang mampu mendeteksi asap rokok dan kemudian menetralisirkanya, alat ini hanya dapat digunakan didalam sebuah ruangan. Asap yang terdeteksi pada sensor kemudian di proses oleh mikrokontroler arduino uno yang kemudian jika kadar asap yang terdeteksi di atas 80ppm akan menghidupkan buzzer. Dengan adanya alat ini diharapkan bisa membantu menetralisir sebuah ruangan yang tadinya terkontaminasi asap bisa menjadi ruangan yang bebas asap. Dalam penelitian ini menggunakan mikrokontroler Arduino Uno dan Sensor MQ-2 sebagai pemrosesan data, penelitian ini memfokuskan untuk bagaimana sensor MQ-2 mendeteksi asap rokok pada suatu ruangan yang terkontaminasi lalu menghasilkan suara buzzer dan mentralisir dengan fan kipas. [4]

Pada penelitian ini "Sistem Monitoring Realtime Pada Asap Rokok Berbasis Mikrokontroler" Jurnal ini menyajikan sistem monitoring real time untuk menampilkan

hasil kadar gas $\mathrm{CO}$ dalam bentuk grafik. Menggunakan sistem simulasi Labview yang aktual menawarkan hasil grafik yang lebih presisi. Dari hasil uji simulasi dan pembahasan tentang monitoring asap rokok dalam suatu ruangan secara realtime menggunakan Labview dapat disimpulkan bahwa rangkaian simulasi monitoring kadar gas $\mathrm{CO}$ pada asap rokok ini dengan menggunakan Mikrokontroler arduino uno dapat bekerja dengan baik sesuai karaktristik sensor Jurnal Ilmiah Fakultas Teknik LIMIT'S Vol.16 No 2 September 202056 MQ-2 yang digunakan dan kadar asap rokok yang terdapat di dalam ruangan telah berhasil ditampilkan di monitoring mengunakan sofware Labview. [5]

Dengan adanya perkembangan teknologi tersebut maka solusi yang telah diambil untuk penelitian, maka Peneliti merancang sebuah sistem monitoring pendeteksi asap rokok. Saat sensor mendeteksi asap rokok, maka buzzer akan berbunyi sebagai tanda peringatan dan kipas akan menyala untuk mensterilkan kembali ruangan yang tercemari oleh asap rokok. Notifikasi akan dikirimkan dari microkontroller ke telegram untuk memberitahu bahwa terdeteksi asap rokok, sehingga perokok yang melanggar aturan merokok di tempat umum bisa di arahkan ke tempat yang sudah disediakan untuk merokok.

Perancangan ini dilakukan dengan menggunakan 1 sensor yaitu : sensor gas. Disamping dari sensor juga penelitian ini menggunakan jaringan wireless (WIFI) untuk mengkoneksian microkontroler dengan telegram yang ada pada smartphone maupun komputer. Pengkoneksian tersebut dilakukan supaya bisa memudahkan dalam memonitoring dan mengatur alat pendeteksi asap rokok tersebut untuk melihat apakah ada asap rokok yang terdeteksi pada suatu ruangan.

\section{METODE PENELITIAN}

Metode penelitian ini menggunakan penelitian eksperimental. Penelitian ini merupakan suatu metode sistematis dan logis untuk menjawab pertanyaan "Jika sesuatu dilakukan pada kondisi-kondisi yang dikontrol dengan teliti, maka apakah yang akan terjadi?". Dalam hubungan ini, peneliti memanipulasi suatu stimuli, treatment, atau kondisi-kondisi eksperimental, kemudian mengobservasi pengaruh atau perubahan yang diakibatkan oleh manipulasi tersebut. Untuk memperoleh pengaruh yang betul-betul bersih dari faktor-faktor yang kemungkinan masuknya pengaruh faktor lain.[6]

Metode pengembangan sistemyang digunakan yaituproses modelPrototyping. Proses model prototyping ini sangat cocok dengan penelitian yang dibuat Peneliti karena dalam purwarupa ini proses masih bisa di evaluasi agar pengimplementasiannya bisa menjadi lebih baik. Dengan menggunakan model prototyping ini pengembang dan pengguna dapat saling berinteraksi selama proses pembuatan alat.[7]

Kelebihan dari model prototyping ini yaitu model ini cukup efektif sebagai paradigma dalam rekayasa perangkat lunak. Dalam model ini pelanggan dan pembuat perangkat lunak mendapatkan kebutuhan dan aturan yang jelas. Ketika diperlihatkan working version, pelanggan bisa langsung 
merasakan seakan itu adalah sistem yang sebenaranya. Untuk kekurangan model ini adalah pelanggan yang melihat working version dari model ini tidak menyadari bahwa mungkin saja rancangan tidak tersusun baik dan prototype dibuat terburu-buru, pengembang kadang-kadang membuat implementasi sembarang karena ini working version cepat selesai, kemudian karena pelanggan sudah melihat prototypenya, pelanggan menjadi tidak sabar untuk melihat versi jadinya.

Selain itu, untuk memodelkan sebuah perangkat lunak dibutuhkan beberapa tahapan didalam proses pengembangannya. Tahapan-tahapan dalam prototyping tersebut adalah sebagai berikut:

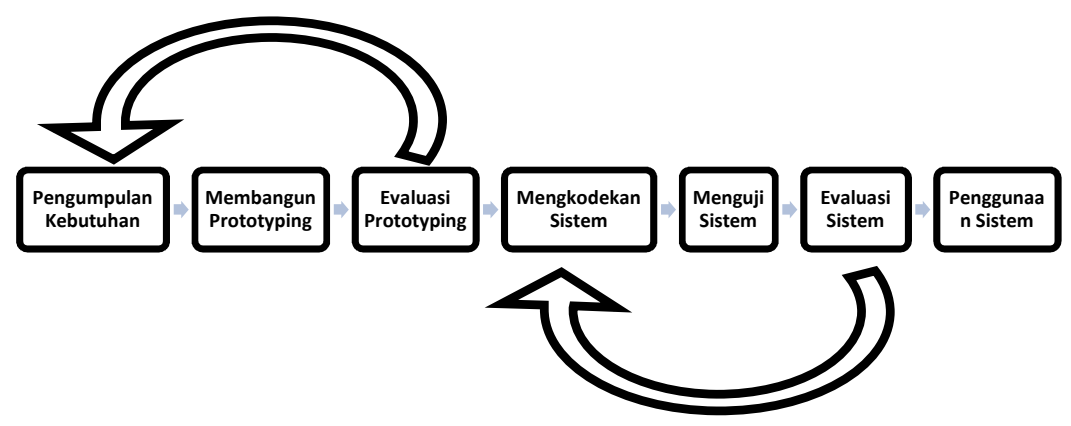

Gambar 1 Proses Model Prototyping

\section{Pengumpulan kebutuhan}

Pengembang dan user atau operator bersama-sama mendefinisikan format dan kebutuhan keseluruhan perangkat lunak, mengidentifikasikan semua kebutuhan, dan garis besar sistem yang akan dibuat.

\section{Membangun Prototyping}

Membangun prototyping alat pendeteksi asap rokok dengan cara membuat perancangan sementara yang berpusat pada penyajian kepada useratau operator (misal dengan membuat contoh input dan output-nya).

\section{Evaluasi Prototyping}

Evalulasi ini dilakukan oleh user atau operator apakah prototyping alat pendeteksi asap rokok sudah sesuai dengan keinginan user atau operator. Jika prototyping sudah sesuai dengan keinginan user atau operator, maka tahapan akan berlanjut kelangkah keempat. Namun jika prototyping belum sesuai dengan dengan keinginan user atau operator maka prototyping akan diperbaiki dan mengulang tahapan-tahapan sebelumnya.

\section{Mengkodekan sistem}

Jika prototyping telah disepakati, maka dalam tahapan ini prototyping akan diterjemahkan ke dalam bahasa pemrograman $\mathrm{C}$.

\section{Menguji Sistem}

Sistem yang sudah menjadi sebuah perangkat lunak yang siap pakai, harus diuji terlebih dahulu sebelum digunakan.

6. Evaluasi Sistem

User atau operator mengevaluasi apakah sistem yang sudah jadi tersebut sesuai dengan yang di harapkan. Jika sudah sesuai, maka tahapan akan dilanjutkan ke tahap terakhir, dan jika belum sesuai maka sistem akan mengulangi tahapan 4 dan 5 .

\section{Menggunakan Sistem}

Perangkat lunak yang sudah di uji dan diterima oleh user atau operator siap digunakan. 


\subsection{Implementasi}

\section{HASIL DAN PEMBAHASAN}

Setelah melakukan analisa dan perancangan, maka sistem tersebut siap diimplementasikan. Tahapan implementasi sistem merupakan suatu tindakan atau pelaksanaan dari sebuah rencana yang sudah disusun secara matang dan terperinci.

Kegiatan implementasi ini meliputi kebutuhan perangkat keras (hardware) dan kebutuhan perangkat lunak (software). Pada sub bagian ini akan menjelaskan tentang tahapan implementasi alat pendeteksi asap rokok.

\subsubsection{Implementasi Hardware}

Berikut dibawah ini tahapan implementasi pada hardware sebagai berikut :

\section{Sensor MQ-135}

Tahapan pertama dilakukan penghubungan antara sensor MQ-135 dengan Wemos D1 ESP8266. Pastikan A0 terhubung dengan benar, agar sensor dapat mengirimkan data yang diterimanya dan mengirimnya ke Wemos D1 8266.

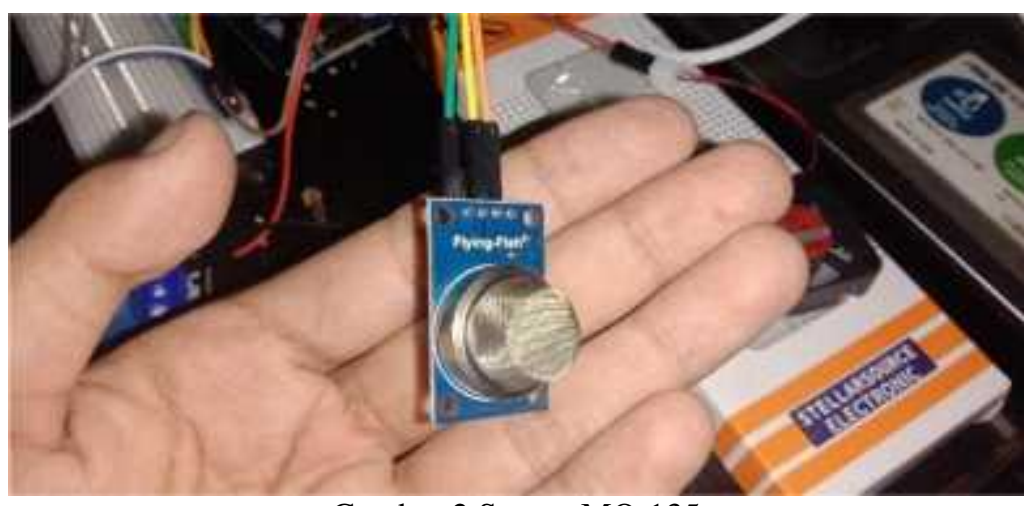

Gambar 2 Sensor MQ-135

2. Kipas DC

Tahapan kedua dilakukan penghubungan antara kipas DC dengan relay. Pastikan pin NO1 terhubung dengan benar dengan kipas DC dan COM1agar kipas dapat menyala.

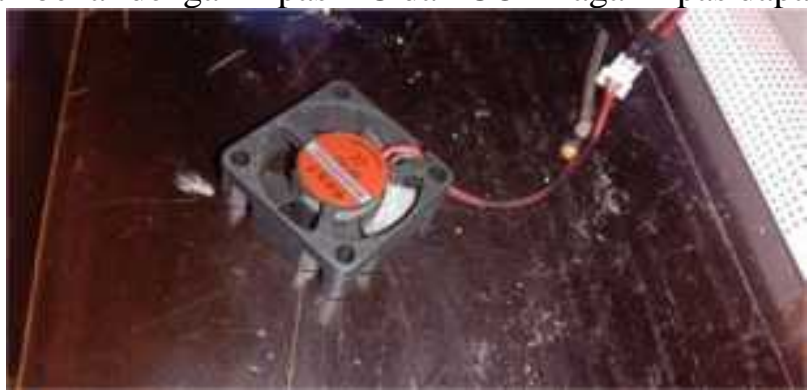

Gambar 3 Kipas DC

\section{Buzzer}

Tahapan selanjutnya menghubungkan antara buzzer dengan PC1 kepada wemos D1 ESP8266. Supaya saat wemos D1 menerima data asap yang dikirim MQ-135, buzzer akan berbunyi. 


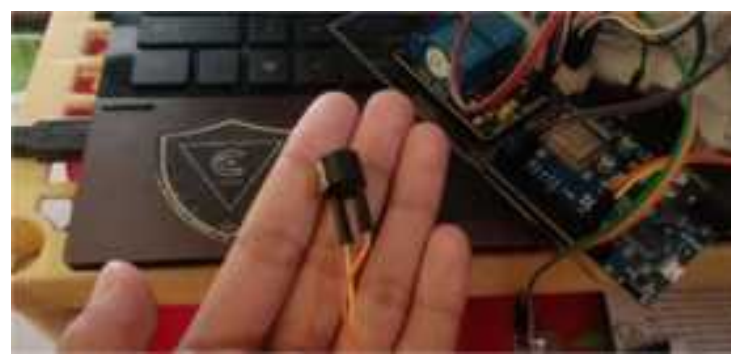

Gambar 4 Buzzer

4. Relay 2 Kaki

Pada relay ini mampu untuk menghantarkan listrik sebesar 220v. Relay ini memiliki 2 kaki namun yang digunakan hanya 1 kaki.

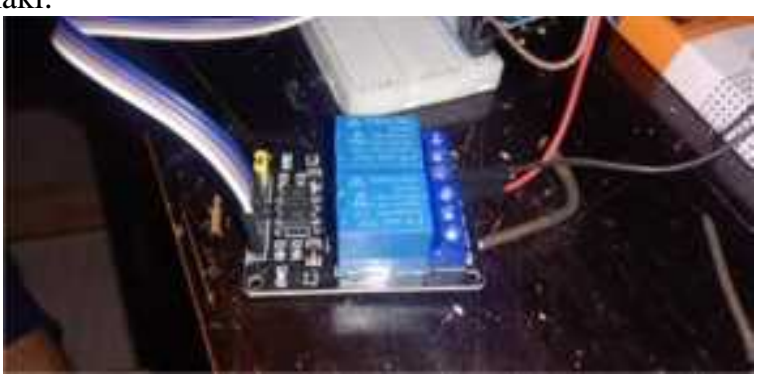

Gambar 5 Relay 2 Kaki

\subsubsection{Hasil Rangkaian Hardware}

Pada tahapan ini merupakan hasil dari perangkaian komponen - komponen alat pendeteksi asap rokok yang tertera pada gambar 6 .

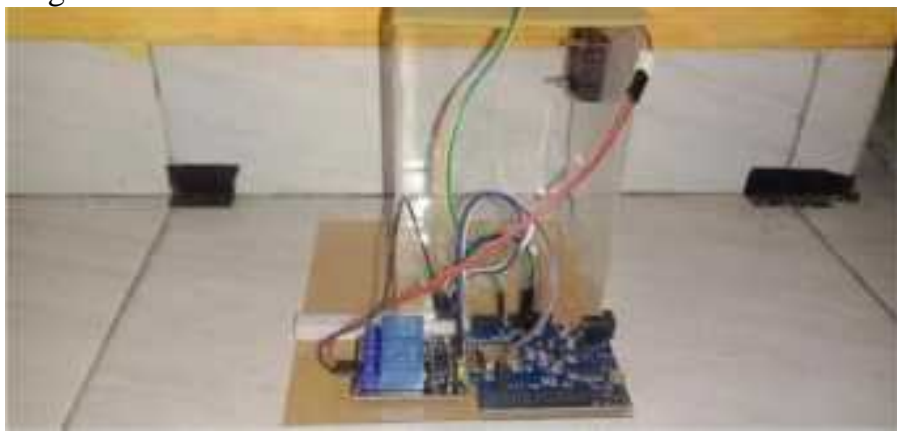

Gambar 6 Hasil Rangkaian Hardware

\subsubsection{Implementasi Perangkat Lunak}

Pada tahap ini dilakukan implementasi dari tahap perancangan dan hasil rancangan kedalam aplikasi telegram.

1. Tampilan Awal Chat Bot 


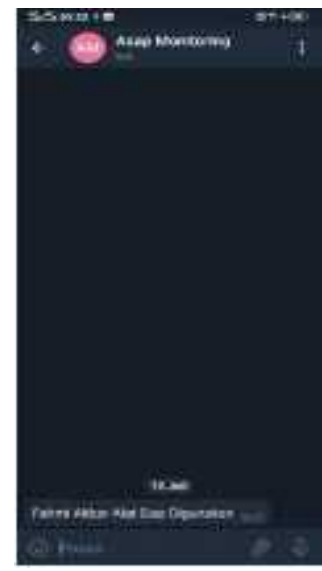

Gambar 7 Tampilan Awal Chat Bot

Tampilan ini merupakan tahapan awal sebelum melakukan monitoring sensor MQ-135. Dimana saat alat pendeteksi asap dinyalakan, alat ini akan mengirimkan notifikasi seperti pada gambar diatas.

2. Tampilan Menu Monitoring

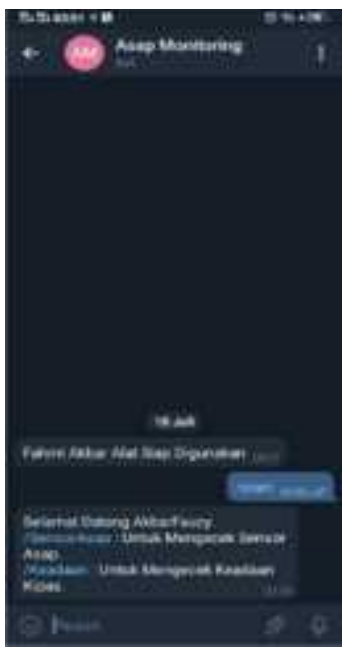

Gambar 8 Tampilan Menu Monioring

Pada tampilan ini terdapat pilihan untuk mengecek keadaan sensor dan kipas DC.

3. Tampilan Status Oksigen

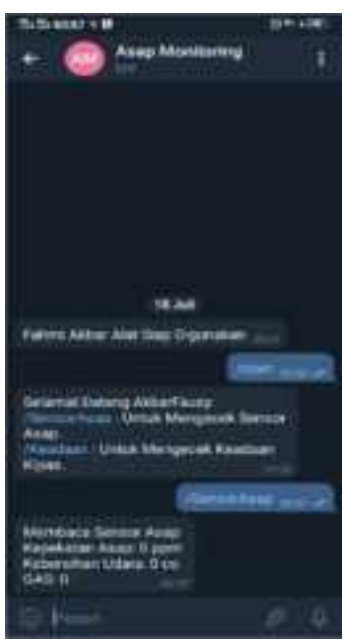

Gambar 9 Tampilan Status Oksigen

Tampilan status udara merupakan tampilan untuk mengecek keadaan udara di dalam ruangan, semakin besar nilai yang ditampilkan di telegram, maka kebersihan udara di ruangan tersebut sudah berkurang. 


\subsection{Pengujian}

\subsubsection{Pengujian Program Aplikasi}

Pengujian perangkat lunak (Program Aplikasi) dilakukan untuk memastikan bahwa program berjalan sesuai dengan tujuan dan meminimalisirkan jika terjadinya sebuah kesalahan. Pengujian ini dilakukan dengan melakukan proses yang diharapkan untuk bisa menganalisa apakah tombol dan data yang diproses sesuai dengan apa yang diharapkan sehingga bisa diketahui bahwa tidak terjadinya error yang timbul akibat tidak kesesuaian isi dari masing masing pilihan.

1. Pengujian Bot Telegram

Tabel 3.1 Hasil Pengujian Tampilan Bot Telegram

\begin{tabular}{|c|c|c|c|}
\hline Data Masukan & Proses yang & Output & Kesimpulan \\
\hline & $\begin{array}{c}\text { Menampilkan Notifikasi } \\
\text { saat alat dihidupkan }\end{array}$ & $\begin{array}{c}\text { Menampilkan ucapan alat siap } \\
\text { digunakan }\end{array}$ & Sukses \\
\hline
\end{tabular}

2. Pengujian Tampilan Telegram

Tabel 3.2 Hasil Pengujian Tampilan Telegram

\begin{tabular}{|l|c|c|c|}
\hline $\begin{array}{c}\text { Data } \\
\text { Masukan }\end{array}$ & Proses yang Diharapkan & Output & Kesimpulan \\
\hline /start & $\begin{array}{c}\text { Menampilkan pilihan untuk } \\
\text { melanjutkan ke proses } \\
\text { selanjutnya }\end{array}$ & $\begin{array}{c}\text { Menampilkan ucapan selamat } \\
\text { datang dan pilihan untuk cek } \\
\text { sensor serta kipas }\end{array}$ & Sukses \\
\hline
\end{tabular}

3. Pengujian Tampilan Sensor MQ-135

Tabel 3.3 Hasil Pengujian Sensor MQ-135

\begin{tabular}{|c|c|c|c|}
\hline $\begin{array}{c}\text { Data } \\
\text { Masukan }\end{array}$ & Proses yang Diharapkan & Output & Kesimpulan \\
\hline /SensorAsap & Menampilkan status asap & $\begin{array}{c}\text { Menampilkan status } \\
\text { kepekatan asap, kebersihan } \\
\text { udara dan Gas }\end{array}$ & Sukses \\
& & & \\
\hline
\end{tabular}

\subsubsection{Kesimpulan Hasil Pengujian}

Alat yang dibuat oleh Peneliti telah berjalan sebagaimana mestinya karena dari hasil yang didapatkan apabila terdeteksi asap rokok, maka tegangan output pada sensor akan naik, sehingga konsentrasi gas akan menurun dan terjadi proses penghilangan oksigen pada ruangan tersebut. Akibatnya permukaan dari muatan negatif oksigen akan berkurang. Hal ini mengakibatkan penurunan resistansi sensor yang juga memiliki sebuah heater(pemanas). Kipas juga berhasil membuang asap yang ada pada ruangan ketika kepekatan asap yang dideteksi sensor MQ-135 sudah mencapai >300ppm. Ketika sensor mendeteksi asap rokok, mikrokontroler Wemos D1 akan mengirimkan notifikasi ke user melalui telegram. Monitoring bisa dilakukan melalui telegram, selama mikrokontroler dan smartphone terkoneksi internet maka proses monitoring bisa dilakukan dimana saja dan kapan saja.

\section{KESIMPULAN}

Peneliti mengemukakan sebuah kesimpulan dalam penelitian ini yang terkait didalamnya berupa:

1. Alat dapat dikembangkan dengan menggunakan sensorMQ-135, serta telah berhasil melakukan koneksi wireless dengan menggunakan Wemos D1 ESP8266.

2. Kualitas udara pada ruangan berhasil dimonitoring melalui telegram.

3. Sensor MQ-135 mendeteksi asap tergantung dari kepekatan asap tersebut. Semakin pekat asap, maka sensor akan semakin cepat mendeteksi asap tersebut.

4. Kipas DC mampu membuang asap rokok dari dalam ruangan 


\section{SARAN}

Adapun saran yang telah dibuat oleh Peneliti dalam mengembangkan alat pendeteksi asap rokok untuk peneliti selanjutnya :

1. Masih banyak yang bisa dikembangkan berupa, seperti penambahan sensor untuk mendeteksi nyala api untuk mengetahui apa ada perokok yang merokok di tempat yang dilarang merokok, jadi tidak hanya mendeteksi dari asapnya saja.

2. Penambahan kamera untuk mengetahui siapa orang yang merokok di tempat yang terdapat larangan merokok.

3. Menambahkan sensor untuk memberitahukan bila ada kerusakan atau gangguan yang terjadi pada kipas.

\section{DAFTAR PUSTAKA}

[1] Dedy Hamdani, Elda Handayani, Eko Risdianto, "Rancang Bangun Alat Pedeteksi Asap Rokok Dan Nyala Api Untuk Penanggulangan Kesehatan Dan Kebakaran Berbasis Arduino Uno Dan GSM SIM900A", Jurnal Ilmu Fisika, ISSN 2614-7386, Maret 2019

[2] Sri Zholehaw, Ali Basrah P, Hamdani, "Sistem Monitoring Realtime Gas Co Pada Asap Rokok Berbasis Mikrokontroler", Teknik Elektro, ISSN 2302-3309, Maret 2019

[3] Dasef Akhwandi, Anton Yudhana, "Sistem Penyegaran Ruangan Dari Asap Rokok Dan Gas Lpg Berbasis Mikrokontroler Atmega8535", Jurnal Ilmu Teknik Elektro Komputer dan Informatika, Juni 2017

[4] Agil Aditya \& dkk. (2017). Alat Pendeteksi Asap Rokok pada Ruangan Menggunakan, Sensor MQ-2 dan Microkontroller Arduino Uno 37-45.

[5] Sri Zholehaw \& dkk. (2019). Sistem Monitoring Realtime Gas CO Pada Asap Rokok Berbasis Mikrokontroler, 17-21.

[6] Hansiswany Kamarga, "Metodologi Penelitian Pedidikan (Sejarah)", Pendidikan Sejarah

[7] Dwi Purnomo, "Model Prototyping Pada Pengembangan Sistem Informasi", Teknik Informatika, ISSN 2503-1945, Agustus 2017 